\title{
PENGARUH UKURAN PARTIKEL, WAKTU DAN SUHU PADA EKSTRAKSI FENOL DARI LENGKUAS MERAH
}

\section{INFLUENCE OF PARTICLE SIZE, TIME AND TEMPERATURE TO EXTRACT PHENOL FROM GALANGAL}

\author{
Rondang Tambun ${ }^{1}$, Harry P. Limbong ${ }^{2}$, Christika Pinem ${ }^{1}$, Ester Manurung ${ }^{1}$ \\ ${ }^{1)}$ Departemen Teknik Kimia, Fakultas Teknik, Universitas Sumatera Utara, \\ Jl. Almamater Kampus USU Medan 20155, Indonesia \\ ${ }^{2}$ Balai Riset dan Standardisasi Industri Medan, Jl. Sisingamangaraja No.24, \\ Medan 20213, Indonesia \\ Email: christikapinem16@yahoo.com
}

\begin{abstract}
Abstrak
Lengkuas merah merupakan salah satu jenis tanaman rempah-rempah yang mengandung senyawa fenol. Pada penelitian ini kandungan fenol dalam fasa cair akan diekstrak dari rimpang lengkuas merah. Variasi yang dilakukan pada penelitian ini adalah waktu ekstraksi (3 jam, 6 jam, 9 jam), suhu $\left(30{ }^{\circ} \mathrm{C}, 45^{\circ} \mathrm{C}, 60{ }^{\circ} \mathrm{C}\right)$ dan ukuran partikel bahan baku (70 mesh, 100 mesh, 140 mesh). Salah satu analisa yang dilakukan pada penelitian ini adalah analisa kadar fenol. Dari hasil penelitian yang dilakukan, hasil kadar fenol tertinggi sekitar $4,5 \%$ diperoleh pada suhu $60^{\circ} \mathrm{C}$ dengan lama ekstraksi 9 jam dan ukuran partikel menggunakan tray 140 mesh.
\end{abstract}

Kata kunci : fenol, lengkuas merah, ekstraksi, rempah-rempah

\begin{abstract}
Galangal is one of spices containing phenol. This study aims to product phenol in a liquid phase from galangal. The variations performed in this study involve the time of extraction (3 hours, 6 hours, 9 hours), temperature $\left(30{ }^{\circ} \mathrm{C}\right.$, $45^{\circ} \mathrm{C}, 60^{\circ} \mathrm{C}$ ) and particle size of raw material (70 mesh, 100 mesh, 140 mesh). One of the analysis in this study is the yield of phenol. The highest phenol in this study is about $4,5 \%$. This result is obtained using 140 mesh of tray at $60^{\circ} \mathrm{C}$ of temperature and 9 hours of extraction time.
\end{abstract}

Keywords : phenol, galangal, extraction, spices 


\section{Pendahuluan}

Indonesia merupakan negara yang terkenal dengan keanekaragaman tanaman terutama hasil pertanian dan rempah-rempahnya. Salah satu tanaman tersebut adalah lengkuas merah (Alpinia purpurata $K$ Schum). Lengkuas telah lama digunakan oleh masyarakat Indonesia, dimana tumbuhan tersebut berperan sebagai penyedap rasa dan berkhasiat sebagai obat. Selain itu lengkuas juga dapat berperan dalam memperpanjang umur simpan atau mengawetkan makanan karena aktivitas anti bakteri yang terkandung didalamnya. Tanaman lengkuas mengandung minyak atsiri yang mengandung senyawa flavonoid, fenol dan terpenoid. Salah satu zat yang kuat digunakan sebagai pengawet alami adalah fenol. Fenol memiliki sifat yang cenderung asam, artinya ia dapat melepaskan ion $\mathrm{H}^{+}$ dari gugus hidroksilnya. Senyawa fenol berfungsi sebagai senyawa aktif antibakteri dan antioksidan yang kuat. Penelitian yang menggunakan bahan rempah-rempah seperti jahe, kunyit, dan cengkeh sebagai pengawet alami telah banyak diteliti $[1,3,7$, 9].

\section{Teori}

Lengkuas atau Laos (Alpinia galanga) merupakan jenis tumbuhan umbi-umbian yang bisa hidup di daerah dataran tinggi maupun dataran rendah. Umumnya masyarakat memanfaatkannya sebagai campuran bumbu masak dan pengobatan tradisional. Pemanfaatan lengkuas untuk masakan dengan cara mememarkan rimpang kemudian dicelupkan begitu saja ke dalam campuran masakan, sedangkan untuk pengobatan herbal yang banyak digunakan adalah lengkuas merah (Alpinia purpurata K Schum). Pohon lengkuas merah hanya sampai 11,5 meter. Bagian tanaman dari lengkuas merah Alpinia purpurata K. Schum yang sering digunakan adalah rimpang. Rimpang lengkuas mengandung minyak atsiri yang terdiri dari metilsinamat, sineol, kamfer, $\delta$-pinen, galangin, dan eugenol. Rimpang lengkuas juga mengandung kamfor, galangol, seskuiterpen dan kristal kuning Selain itu, rimpang lengkuas merah Alpinia purpurata K. Schum mengandung senyawa flavonoid, kaempferol-3rutinoside dan kaempferol-3-oliucronide

\section{Kandungan Kimia}

Rimpang lengkuas segar mengandung air sebesar $75 \%$, dan dalam bentuk kering mengandung karbohidrat $22,44 \%$, protein $3,07 \%$ dan senyawa kamferid $0,07 \%$. Lengkuas merah mengandung kurang lebih $1 \%$ minyak atsiri berwarna kuning kehijauan yang terutama terdiri dari metilsinamat $48 \%$, sineol $20 \%-30 \%$, eugenol, kamfer $1 \%$, seskuiterpen, $\delta$-pinen, galangin, dan lain-lain. Selain itu rimpang juga mengandung senyawa fenol, flavonoid dan terpenoid. Kandungan fitokimia yang utama adalah fenol yang merupakan senyawa yang berasal dari tumbuhan yang umumnya ditemukan di dalam vakuola sel. Fenol terdiri dari beraneka ragam struktur dengan ciri khas berupa cincin aromatik yang mengandung satu atau dua gugus hidroksil. Salah satu golongan terbesar fenol adalah flavonoid, dan beberapa golongan bahan polimer penting lainnya antara lain: lignin, melanin dan tanin $[2,5,8]$.

\section{Ekstraksi}

Ekstraksi adalah kegiatan penarikan kandungan kimia yang dapat larut sehingga terpisah dari bahan yang tidak dapat larut dengan menggunakan suatu pelarut cair. Senyawa aktif yang terdapat dalam berbagai simplisia dapat digolongkan kedalam golongan minyak atsiri, alkaloida, flavanoida, dan lain-lain. Dengan diketahuinya senyawa aktif yang dikandung simplisia akan mempermudah pemilihan pelarut dengan cara ekstraksi yang tepat. Ekstrak adalah sediaan kering, kental, atau cair dibuat dengan menyari simplisia nabati atau hewani menurut cara yang cocok, diluar pengaruh cahaya matahari langsung [4]. Ekstraksi merupakan metode pemisahan suatu zat berdasarkan pelarut yang tepat, baik itu pelarut organik atau pelarut anorganik. Secara umum pelarut etanol merupakan pelarut yang banyak digunakan dalam proses isolasi senyawa organik bahan alam karena dapat melarutkan seluruh golongan metabolit sekunder [6]. Faktor-faktor yang mempengaruhi proses ekstraksi antara lain adalah:

a. Ukuran bahan

Pengecilan ukuran bertujuan untuk memperluas permukaan bahan sehingga mempercepat penetrasi pelarut ke dalam bahan yang akan diekstrak.

b. Suhu ekstraksi

Ekstraksi akan lebih cepat dilakukan pada suhu tinggi.

c. Pelarut

Larutan yang akan dipakai sebagai pelarut merupakan pelarut pilihan yang terbaik.

\section{Fenol}

Kandungan fitokimia yang utama adalah fenol yang merupakan senyawa yang berasal dari tumbuhan yang umumnya ditemukan di dalam vakuola sel. Fenol terdiri dari beraneka ragam struktur dengan ciri khas berupa cincin aromatik yang mengandung satu atau dua gugus hidroksil. Salah satu golongan terbesar fenol adalah flavonoid, dan beberapa golongan bahan polimer penting lainnya antara lain: lignin, melanin dan tanin. Senyawa fenol memiliki beberapa sifat antara lain: mudah larut dalam air, cepat membentuk kompleks dengan protein dan sangat peka terhadap oksidasi enzim. Anggota fenol yang sederhana merupakan zat padat dengan titik lebur rendah. Karena adanya 
ikatan hidrogen diantara molekul-molekulnya, maka titik didih cairannya tinggi. Fenol $\left(\mathrm{C}_{6} \mathrm{H}_{5} \mathrm{OH}\right)$ sedikit larut dalam air (9 g per $100 \mathrm{~g}$ air) karena bobot molekul air itu rendah dan turun titik beku molal dari fenol itu tinggi, yaitu 7,5 maka campuran fenol dengan 5-6\% air telah terbentuk cair pada temperatur biasa. Bila dalam struktur fenol tidak terdapat gugus penyebab timbulnya warna, maka senyawanya juga tidak berwarna.

\section{Metodologi Penelitian}

Bahan baku yang digunakan dalam penelitian ini adalah rimpang lengkuas yang berasal dari ladang di daerah Kampung Lalang, Kabupaten Deli Serdang, pelarut etanol $96 \%, \mathrm{NaOH} 0,1 \mathrm{~N}$, dan $\mathrm{H}_{2} \mathrm{O}$, sedangkan peralatan yang digunakan adalah neraca analitik, alat-alat gelas, botol kaca, aluminium foil, rotary vacuum evaporator, pipet tetes, kertas saring, corong kaca, oven, pisau, erlenmeyer, ballmiil, hot plate, termometer, piknometer, $\mathrm{pH}$ meter.

\section{Hasil dan Pembahasan}

\section{Pengaruh Ukuran Partikel Terhadap Yield Fenol}

Pada penelitian ini, yang dimaksud dengan sampel yang berukuran 70 mesh adalah partikel yang lolos dari tray 70 mesh tetapi tertahan di tray 100 mesh. Sampel yang berukuran 100 mesh adalah partikel yang lolos dari tray 100 mesh tetapi tertahan di tray 140 mesh, sedangkan sampel yang berukuran 140 mesh adalah partikel yang lolos dari tray 140 mesh.

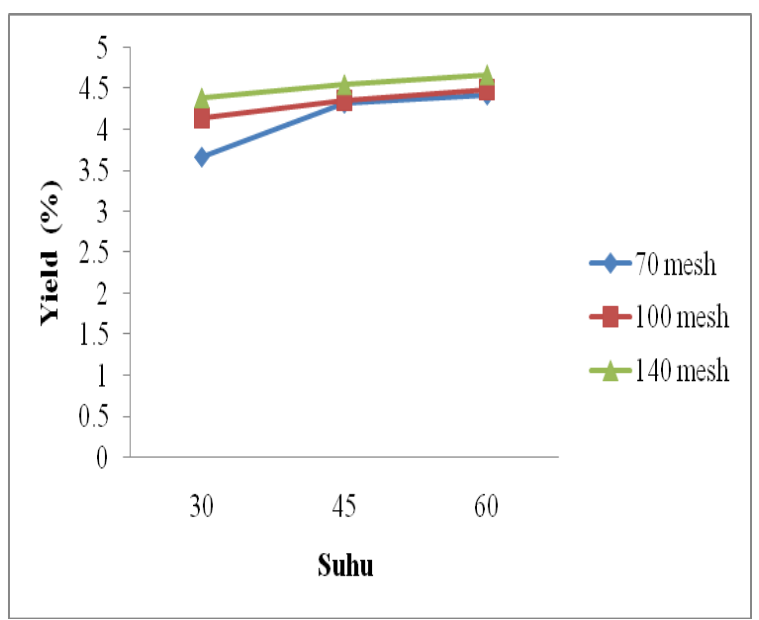

Gambar 1. Pengaruh ukuran partikel dan suhu terhadap kadar Fenol pada waktu 9 jam

Pada gambar 1 dapat dilihat pengaruh ukuran partikel dan suhu terhadap kadar Fenol pada waktu 9 jam. Pada ukuran partikel 70 mesh, 100 mesh, dan 140 mesh dengan waktu ekstraksi selama 9 jam diperoleh kadar fenol yang semakin banyak dengan meningkatnya suhu. Demikian juga dengan ukuran partikel, semakin kecil ukuran partikel, maka luas permukaan zat tersebut akan semakin meningkat, sehingga akan mempercepat kelarutan suatu zat. Hasil yang diperoleh telah sesuai dengan teori bahwa semakin halus partikel yang digunakan, maka semakin banyaknya pori-pori yang terbentuk pada serbuk dari lengkuas merah sehingga mengakibatkan peningkatan jumlah kadar fenol yang mudah diserap.

\section{Pengaruh Suhu Dan Waktu Ekstraksi Terhadap Yield Fenol}

Pengaruh suhu dan waktu terhadap kadar fenol yang dihasilkan pada ukuran partikel 100 mesh dapat dilihat pada Gambar 2.

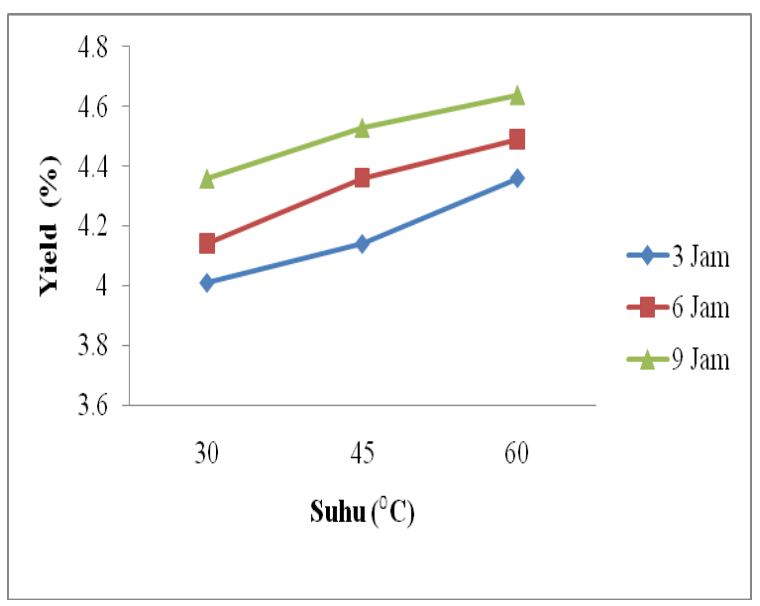

Gambar 2. Pengaruh suhu dan waktu terhadap yield fenol pada 100 mesh

Pada gambar 2 dapat dilihat bahwa kadar fenol semakin banyak diperoleh seiring dengan penambahan waktu dan suhu ekstraksi yang digunakan. Kadar fenol yang paling banyak diperoleh pada suhu ekstraksi $60{ }^{\circ} \mathrm{C}$ dengan waktu ekstaksi 9 jam. Hal ini disebabkan semakin lama waktu dan naiknya suhu ekstraksi yang digunakan, maka pelarut semakin mudah untuk menarik zat-zat kimia yang terdapat pada serbuk lengkuas tersebut. Suhu sangat berpengaruh dalam menentukan kadar zat fenol pada saat proses ekstraksi rimpang lenggkuas merah.

Kadar fenol yang paling rendah dapat dilihat pada suhu $30{ }^{\circ} \mathrm{C}$ dengan waktu ekstraksi 3 jam yaitu sebesar 4,01\%. Hal ini disebabkan karena sedikitnya waktu ekstraksi yang digunakan pada saat proses ekstraksi, sehingga pelarut sulit untuk menembus dinding-dinding pada serbuk lengkuas.

\section{Kesimpulan}

Kesimpulan yang dapat diambil dari penelitian ini adalah sebagai berikut :

1. Kadar fenol tertinggi sekitar $4,5 \%$ diperoleh pada ekstraksi berukuran 140 mesh dalam waktu 9 jam dengan kondisi suhu $60{ }^{\circ} \mathrm{C}$. 
2. Semakin kecil ukuran partikel lengkuas merah, maka kadar fenol yang diperoleh akan semakin banyak.

3. Semakin tinggi suhu yang digunakan pada ekstraksi dari lengkuas merah, maka kadar fenol yang diperoleh akan semakin meningkat.

4. Semakin lama waktu ekstraksi yang digunakan, maka semakin banyak zat-zat yang diserap.

\section{Daftar Pustaka}

[1] A. M. Ibrahim, Yunianta, F. H. Sriherfyna, Pengaruh Suhu Dan Lama Waktu Ekstraksi Terhadap Sifat Kimia Dan Fisik Pada Pembuatan Minuman Sari Jahe Merah (Zingiber officinale var. Rubrum) Dengan Kombinasi Penambahan Madu Sebagai Pemanis, Jurnal Pangan dan Agroindustri Vol. 3 No 2 p.530-541, April 2015

[2] C. P. Victório, R. M. Kuster, C. L. S. Lage, Detection of flavonoids in Alpinia purpurata (Vieill.) K. Schum. leaves using highperformance liquid chromatography, Rev. Bras. Pl. Med., Botucatu, v.11, n.2, p.147-153, 2009

[3] D. Anggoro , R. S. Rezki, Siswarni MZ (2015). "Ekstraksi Multi Tahap Kurkumin Dari Temulawak (Curcuma Xanthorriza Roxb.) Menggunakan Pelarut Etanol”. Jurnal Teknik Kimia USU, Vol. 4, No. 2, Juni 2015.

[4] Depkes RI, Parameter Standar Umum Ekstrak Tumbuhan Obat,Cetakan Pertama, Jakarta, 2000.

[5] E. Sinaga (2003). Alpinia galangal (L.) Willd. Pusat Penelitian dan Pengembangan Tumbuhan Obat UNAS,www.warintek.hol.es/artikel/ ttg tanaman_obat/unas/Lengkuas.pdf (diakses Desember 2015).

[6] Hernani, T. Marwati, C. Winarti, Pemilihan Pelarut Pada Pemurnian Ekstrak Lengkuas (Alpinia galanga) Secara Ekstraksi, Jurnal Pascapanen Vol. 4 No. 1, 2007, Hal : $1-8$.

[7] L.B.S. Kardono dan R.T Dewi, (1998). Evaluasi Kandungan Antioksidan Dan Senyawa Fenolik Dalam Rempah-rempah Endemik Indonesia. Prosiding Seminar Nasional Teknologi Pangan dan Gizi, Yogyakarta

[8] N. S. Handajani, T. Purwoko, Aktivitas Ekstrak Rimpang Lengkuas (Alpinia galanga) terhadap Pertumbuhan Jamur Aspergillus spp. Penghasil Aflatoksin dan Fusarium moniliforme, BIODIVERSITAS, Volume 9, Nomor 3 Juli 2008

[9] S. Florensia, P. Dewi, N. R. Utami, Pengaruh Ekstrak Lengkuas pada Perendaman Ikan Bandeng terhadap Jumlah Bakteri, Unnes Journal of Life Science, Vol 1, No. 2, 2012 